\title{
MACRO E MICROMORFOLOGIA DE FERRICRETES NODULARES DESENVOLVIDOS DE ARENITO DO GRUPO BAURU, FORMAÇÃO ADAMANTINA ${ }^{(1)}$
}

\author{
M. R. COELHO ${ }^{(2)}$, P. VIDAL-TORRADO ${ }^{(3)} \&$ F. S. B. LADEIRA ${ }^{(4)}$
}

\begin{abstract}
RESUMO
Nas paisagens do norte do estado de São Paulo, sob domínio do Planalto Ocidental, ferricretes ocorrem em diferentes níveis topográficos e, apesar de pouco documentados, constituem feições que se repetem com freqüência sobre os arenitos cretácicos do Grupo Bauru, Formação Adamantina. Realizou-se um estudo morfológico, em diferentes escal as de observação, a fim de elucidar a gênese desses ferricretes (plintita e petroplintita) encontrados no terço inferior de uma vertente dominada por solos com B textural. A área estudada localiza-se na Estação Experimental de Agronomia de Pindorama, do Instituto Agronômi co de Campinas (IAC), região norte do estado de São Paulo. Dois perfis foram selecionados para a descrição morfológica detal hada e para as observações micromorfológi cas com lupa binocular e microscópio petrográfico. As evidências macro e micromorfológicas dos ferricretes revelam uma origem associada à lixiviação do ferro ferroso a montante da paisagem e reprecipitação na zona de vadosa. Esses ferricretes apresentaram diferentes fábricas internas, a maioria dos quais com estruturas de degradação, evidenciando o desmantelamento atual da couraça. As diferenças nas fábricas internas estão rel acionadas com a distribuição do esqueleto e do plasma: alguns apresentam esqueleto bem selecionado, com predominância de areia muito fina, enquanto em outros predomina a areia média; outros, ainda, mostram esqueleto pouco selecionado, assemelhando-se ao fundo matricial interglebular; a maioria mostra alguns volumes ocupados apenas por plasma. Demonstra-se que fatores pedo-lito-biológicos estão envol vidos nessa diversidade entre ferricretes de um mesmo horizonte, formando in si tu glébulas tão distintas em suas fábricas, que podem ser erroneamente interpretadas como provenientes de diferentes locais da paisagem, transportadas e depositadas nas baixas encostas durante a gênese dos ferricretes.
\end{abstract}

Termos de indexação: gênese de ferricretes, micromorfologia, petroplintita, laterita, relações solo-paisagem.

(1) Parte da Tese de Mestrado, apresentada pel o primeiro autor ao curso de pós-graduação em Sol os e Nutrição de Plantas da Escola Superior de Agricultura "Luiz de Queiroz" - ESALQ/USP. Recebido para publicação em abril de 2000 e aprovado em dezembro de 2000.

(2) Assistente Técnico de Pesquisa Científica e Tecnológica do Centro de Sol os e Recursos Agroambientais, Instituto Agronômico de Campinas - IAC. Caixa Postal 28, CEP 13020-900 Campinas (SP). E-mail: mrcoel ho@barao.iac.br

(3) Professor do Departamento de Ciência do Solo, Escola Superior de Agricultura “Luiz de Queiroz" - ESALQ/USP. Caixa Postal 09, CEP 13418-900 Piracicaba (SP). Bolsista do CNPq. E-mail: pablo@carpa.ciagri.usp.br

(4) Doutorando do Curso de Pós-graduação em Geografia Física do Departamento de Geografia, Universidade de São Paulo - USP. E-mail: fsbladeira@terra.com.br 


\author{
SUMMARY: MACRO AND MICROMORPHOLOGY OF NODULAR \\ FERRICRETES DEVELOPED OVER SANDSTONE IN THE \\ NORTH OF SÃO PAULO, BRAZIL
}

\begin{abstract}
On the landscape of theE astern Plateau, north of theState of São Paulo, Brazil, there areferricretes in different el evations. Although thesefeatures arerel ati vel y frequent over the cretaceous sandstone (Adamantina Formation, Bauru Group), littl einvestigation has been carried out on their genesis. A morphol ogical study at different levels of observation was conducted in order to elucidate the genesis of ferricretes (plinthite and petroplinthite), occurring at the toeslope of a landscape where soils with argillic horizon predominate, at the Pindorama Experimental Station of the Agronomic Institute (IAC). Two soil profiles were selected for detailed morphological description and samples taken for micromorphological observation using a binocular (reflected light) and a petrographic microscope. The macro and micromorphol ogical evidence showed that ferricrete genesis is associated with the removal of ferrous iron from the upper slope position by throughflow and reprecipitation in thevadosezone. Theseferricretes showed different internal fabrics, most having structures of degradation, giving evidencethat theironstonelayer is currently being broken down. The fabric differentations are related to the skeleton and plasma distribution. Some ferricretes have well selected skeleton, with predominance of very fine sand, others have predominance of medium-size sand and yet others have poorly sel ected skel etons, resembling the matrix-s intergl aebules. Most of the glaebules show some volume occupied by plasma only. It is shown that pedo-lito-biological factors are involved in the diversity of ferricretes of one soil horizon. Thus, "in situ" glaebules well differenciated in their fabric may be mistakenly interpreted as having been origi nated at different landscape positions and deposited at thelower positions during ferricreteformation.
\end{abstract}

Index therms: ferricretes formation, micromorphol ogy, petroplinthite, laterite, soil-landscape relationships.

\section{INTRODUÇÃO}

Há quase dois séculos, em 1807, Buchanan sugeriu o termo laterita (do latim o termo later significa tijolo) para designar um material avermel hado apropriado para construções de casas. De lá para cá, muito se evoluiu nos estudos dos materiais ferruginosos endurecidos de ampla ocorrência nas regiões tropicais, uma vez que os fenômenos de laterização são rel evantes ao geól ogo, interessado nos recursos minerais correlatos, ao geormorfól ogo, preocu pado com a evolução do rel evo tropical, bem como ao pedól ogo, no aproveitamento agrícola dos solos (Bigarella et al., 1996).

Essa abrangência interdisciplinar favoreceu a inexistência de uma linguagem comum entre os diferentes especialistas que lidam com as lateritas, e muita confusão ainda perdura em torno da definição do assunto. Assim, o termo ferricrete foi aqui escolhido para se referir aos materiais ferruginosos endurecidos sem nenhuma implicação genética, envolvendo tanto plintita como petropl intita, visando caracterizá-lo a fim de elucidar os diversos mecanismos envolvidos na sua gênese.
A ocorrência de níveis ferruginizados éfreqüente em sol os derivados da F ormação Adamantina, região norte do estado de São Paulo, onde, muitas vezes, ocorrem perfis completamente dominados por essas fei ções. Esses materiais apresentam-se divergentes nos perfis quanto à profundidade de ocorrência, quantidade, espessura do horizonte ferricrete, padrão de distribuição, morfologia, classes e atributos dos sol os associados e posição que ocupam na paisagem.

Assim, sua presença e suas diversificações podem afetar significativamente o comportamento físicoquími co dos solos, fenômenos ainda pouco conhecidos (Batista \& Santos, 1995), e, mais particularmente, esses materiais podem afetar os seguintes atributos dos solos: densidade, capacidade de retenção deágua, infiltração, erodibilidade, volume explorado pelas raízes, capacidade de troca catiônica (CTC), textura e estrutura, fatores que influem no comportamento hidrológico, bem como na produtividade dos solos.

Portanto, não só o conhecimento da dinâmica de formação e evolução dos ferricretes e dos sol os que desenvolvem essas feições ferruginosas, mas também as peculiaridades que afetam seu comportamento 
devem ser elucidados para que se possa proceder ao uso e manejo adequado desses solos (Batista \& Santos, 1995).

Dos trabal hos de diversos pedólogos, como Boulet et al. (1982), Castro (1989b) e Ladeira (1995), podese concluir que a integração e a hierarquização das informações, obtidas a partir de estudos morfológicos em diferentes escalas de observação, permitem avaliar, em primeira instância, a dinâmica pedogenética, a qual poderá ser comprovada a posteriori com outras análises físicas, químicas e mineralógicas.

No caso de feições pedológicas muito contrastantes com a matriz do solo, como é o caso dos ferricretes e de horizontes muito distintos, esse estudo morfol ógi co pode ser ainda mais poderoso em suas avaliações, pois, nesses casos, as evidências macro e micromorfológicas costumam ser bastante claras e contundentes, e a observação detal hada de sua organização possibilita interpretações precisas da dinâmica atual e passada dos solos.

Apesar da vasta extensão que a Formação Adamantina do Grupo Bauru ocupa nas regiões oeste e norte do estado de São Paulo, são pou cos os estudos que procuram avaliar suas características e elucidar a gênese dos solos associados. Por outro lado, trabalhos acerca da gênese de solos derivados dos sedimentos da Formação Marília, membro mais recente do Grupo Bauru, foram realizados no estado deSão Paulo (Lepsch et al., 1977a,b; J imenez Rueda \& Demattê, 1988; Castro, 1989b; MarquesJ r., 1995). Nenhum desses estudos relata a ocorrência de níveis ferricretizados na paisagem, o que leva a supor uma diferente natureza geoquímica entre os sedimentos das duas F ormações.
O presente trabal hoteve como principal objetivo caracterizar macro e micromorfologicamente as diferentes feições ferruginosas, bem como os perfis de solo onde ocorrem, fornecendo subsídios para elucidar os mecanismos envolvidos na gênese dos ferricretes.

\section{MATERIAL E MÉTODOS}

O estudo foi realizado na Estação Experimental de Agronomia de Pindorama do Instituto Agronômico de Campinas (IAC), região norte do estado de São Paulo. A estação localiza-se ao sul do município de Pindorama, próximo às coordenadas 21013' de latitude sul e 48은 de longitude oeste do meridiano de Greenwich. Geol ogicamente, a área é recoberta pela Formação Adamantina do Grupo Bauru, do Cretáceo Superior, a qual é caracterizada por arenitos de granulação fina a muito fina, alternados com lamitos, siltitos earenitos lamíticos. Também são encontrados neste Grupo cimento e nódul os carbonáticos (Soares et al., 1980).

O clima da região enquadra-se no tipo Aw da classificação de Köppen, definido como tropical úmido com estação chuvosa no verão e seca no inverno. A temperatura média dos três meses de verão (dezembro, janeiro e fevereiro) situa-se na faixa de $24,0^{\circ} \mathrm{C}$, sendo de $19,5^{\circ} \mathrm{C}$ a média dos três meses de inverno (junho, julho e agosto), com uma preci pitação média anual em torno de $1.390 \mathrm{~mm}$.

Em um levantamento pedológico detalhado realizado na Estação Experimental, Lepsch \& Valadares (1976) mapearam sol os classificados como

\section{Quadro 1. Níveis de observação morfológica}

\begin{tabular}{|c|c|c|c|}
\hline Nível de observação & Metodologia & Observação & Escala \\
\hline Vertente & $\begin{array}{l}\text { Tradagens com espaçamentos regulares, profundas } \\
\text { e superficiais, etc. I dentificação do segmento onde } \\
\text { ocorrem ferricretes }\end{array}$ & Campo & $1: 500$ \\
\hline Segmento de vertente & $\begin{array}{l}\text { I dentificação dos limites laterais e em profundidade dos } \\
\text { horizontes com tradagens e aberturas de minitrincheiras }\end{array}$ & Campo & $1: 50$ \\
\hline Perfil & Separação dos horizontes & Campo & $1: 1$ \\
\hline Horizontes & $\begin{array}{l}\text { Descrição morfológica detal hada, segundo } \\
\text { Lemos \& Santos (1996) }\end{array}$ & Campo - Lupa de bolso & 1:1 e $10: 1$ \\
\hline $\begin{array}{l}\text { Superfície de glébulas } \\
\text { e dos agregados }\end{array}$ & $\begin{array}{l}\text { Observação e descrição de feições pedológicas } \\
\text { e de estrutura de rocha }\end{array}$ & Laboratório - Lupa de mesa & 2 a $30: 1$ \\
\hline $\begin{array}{l}\text { Interior de glébulas } \\
\text { e agregados }\end{array}$ & Descrição micromorfológica, segundo Brewer (1976) & $\begin{array}{l}\text { Laboratório - Microscópio } \\
\text { petrográfico }\end{array}$ & 40 a $200: 1$ \\
\hline
\end{tabular}


Concrecionários L ateríticos, situados noterço inferior das vertentes. Selecionou-se uma dessas vertentes para o estudo seqüencial da morfologia dos ferricretes. As análises morfológicas obedeceram à seguinte escal a de observação: vertente- segmento de vertente - perfis - horizontes-superfície deagregados eglébulas - interior de glébulas e de agregados (Quadro 1).

Após a identificação do segmento de vertente (meia encosta inferior) dominado por solos argissól i cos com ocorrência de pl intita, petroplintita emosqueados, situação representativa da paisagem local, seguiu-se um estudo bidimensional da configuração lateral dos diferentes horizontes, segundo os procedimentos propostos por Boulet et al. (1982) e, em seguida, foram sel ecionados os locais para a abertura de duas trincheiras, identificadas aqui como P1 e P2.

Realizada a descrição morfológica dos perfis, seguindo especificações de Lemos \& Santos (1996), coletaram-se amostras indeformadas e orientadas dos princi pais horizontes e das transições entreeles para fins micromorfológicos. A impregnação com resina pol iéster ea preparação das lâminas del gadas seguiram os procedimentos descritos por Castro (1985). A pós endurecimento, as amostras foram cortadas em blocos de dimensão aproximada de $12 \times 8 \times 3 \mathrm{~cm}$, analisadas detal hadamente em lupa binocular, a fim de selecionar os campos mais significativos e representativos do material estudado para confecção das lâminas delgadas. As análises micromorfológicas, bem como as fotomicrografias, foram realizadas em fotomicroscópio petrográfico Zeiss, seguindo os critérios estabelecidos por Brewer (1976) e compilações realizadas por Castro (1989a).

Os sol os foram classificados no Sistema Brasilei ro deClassificação deSolos (E MBRAPA, 1999) a partir dos resultados obtidos por Coel ho (1998) para a área estudada.

\section{RESULTADOSE DISCUSSÃO}

Os horizontes ferricretes estão limitados ao terço inferior da vertente. A montante desses materiais ferruginosos, do topo à baixa meia encosta da toposseqüência, os solos apresentam horizonte B textural evariação em al guns atri butos morfológicos, como a espessura do horizonte $\mathrm{E}$, pertencendo, porém, todos à classe dos Argissol os Vermel hoAmarelos abrúpticos. A figura 1 representa a toposseqüência predominanteda região, evidenciando a espessura dos sol os (atéà rocha) ea localização da vertente e dos perfis estudados.

Noterço final da vertente, onde foram abertas as duas trincheiras, o desaparecimento das feições fer ruginosas a montante destas estabel eceu olimite superior do segmento estudado, sendo seu limite inferior o sopé da vertente, onde mosqueados constituem as únicas feições ferruginosas.
O perfil P 1 apresenta a seqüência ea morfologia dos horizontes indicados no quadro 2 e figura $2 \mathrm{a}$, onde se observam dois exíguos horizontes acima do horizonte ferricrete, ambos de textura areia-franca. Sua cor varia de 7,5 YR 4/2 (bruno-escuro), no horizonte A, para 7,5 YR 4/4 (bruno-escuro), no horizonte $\mathrm{E}$. J á nos horizontes $\mathrm{F}$ eCf, a matriz friável onde as glébulas estão insertas é de coloração vermel ho-amarelada (5YR 4/6).

Dois horizontes glebulares ( $F$ e $C f$ ) foram identificados, descritos eamostrados. No horizonte $F$, há uma predominância de glébulas em relação à matriz, sendo $80 \%$ (volume/volume) do horizonte predominantemente glebular e os $20 \%$ restantes representam o sol o circundante às glébulas (matriz interglebular). No entanto, no horizonte $\mathrm{Cf}$, a proporção da matriz interglebular em relação às glébulas é maior, sendo caracterizado por uma relação de $40 \%$ de glébulas $/ 60 \%$ de matriz.

Abaixo dos horizontes glebulares, o material saprolítico é progressivamente manchado em tons esbranqui çados à medida que se aprofunda no perfil. Colorações vermel has (2,5 YR 4/8) no horizonte $\mathrm{Cr}$ são progressivamente substituídas por manchas cinzas (5YR 6/1) eamarelo-avermel hadas (7,5 YR 6/ 6) nos horizontes Crgl e Crg2, juntamente com o aumento da umidade e com a profundidade. No Cr, notaram-se revestimentos iluviais e contínuos (cer osidade forte e abundante) de col oração brunoforte $(7,5 Y R$ 5/6) envolvendo os fragmentos de arenito semidecomposto. Comparado com a cor da matriz intergl ebular dos horizontes $\mathrm{F}$ e Cf (5YR 4/ 8), o matiz mais amarelo do revestimento sugere a remoção de ferro no transporte das argilas provindas desses horizontes, as quais foram, posteriormente, depositadas nos horizontes sotopostos.

As classes texturais deste perfil são areia-franca, nos horizontes A e E, passando para franco-argiloarenosa, na matriz intergl ebular, permanecendo com essa mesma dasse textural, no horizonte $\mathrm{Cr}$, podendo ser atribuída a presença de cerosidade forte e abundante neste último à migração de argila, como já foi sugerido e observado nas análises micromorfológicas. I sso écorroborado pela diminuição da argila em profundidade e pela drástica redução da quantidade e do grau de desenvolvimento da cerosidade, embora os processos de intemperismo da rocha e formação de solos possam dar origem a minerais na fração argila.

Cinco propriedades macromorfológicas foram consideradas relevantes para a caracterização, diferenciação ou interpretação genética das feições ferruginosas, possibilitando a separação dos dois horizontes gl ebulares ( $F$ eCf) na descrição dos perfis P1 e P2, tal como relatados acima, seguindo as recomendações de Lemos \& Santos (1996). A dureza do material, que é expressa pela sua resistência quando submetido a esforços com as mãos, é uma medida do grau de cimentação das glébulas e 


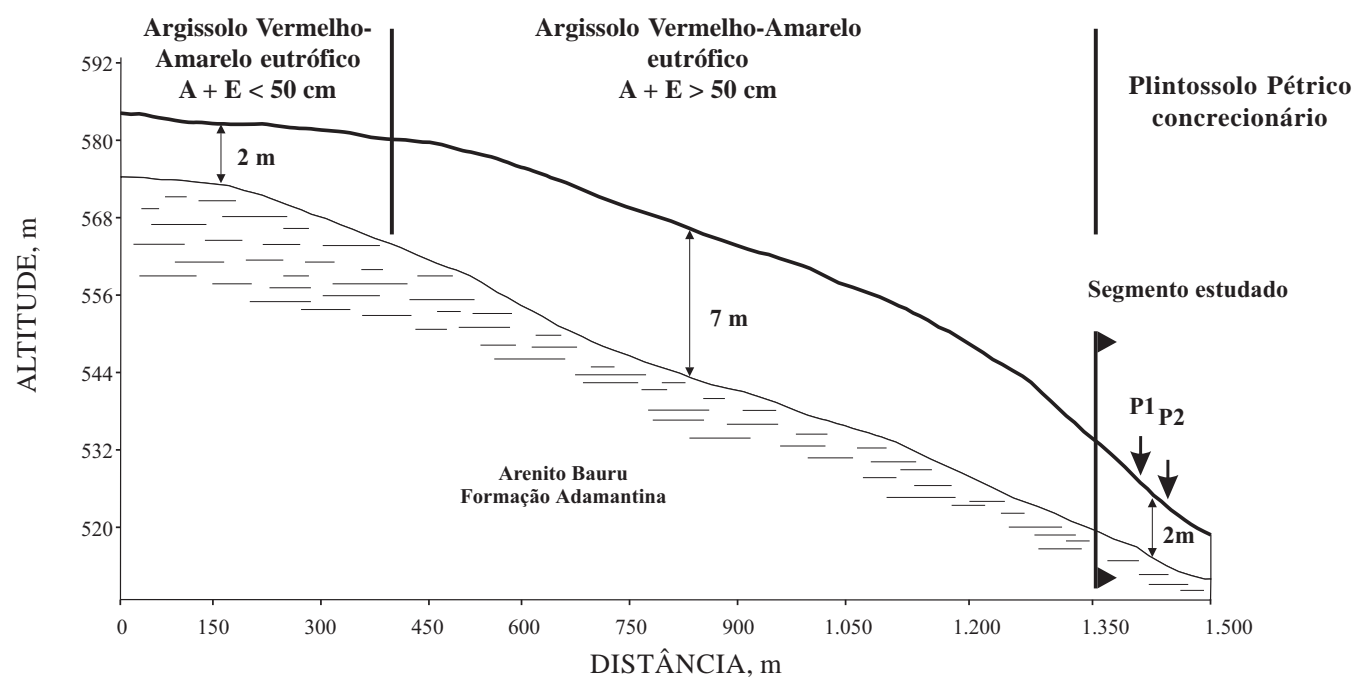

Figura 1. Distribuição dos solos na paisagem e localização do segmento de vertente e dos perfis estudados.

possibilita identificar seu estádio de desenvol vimento. A cor é usada como uma medida do tipo e forma de ferro nos sol os e, juntamente aos atributos tamanho e quantidade, pode constituir uma ferramenta útil na caracterização, distinção e interpretação genética entre diferentes feições ferruginosas.

As glébulas do horizonte F (perfil P1) foram caracterizadas pela el evada dureza, não possi bilitando o rompimento com as mãos. Essa dureza resulta em uma resistência dos ferricretes à penetração radicular, reduzindo a profundidade efetiva dos sol os. Seus diâmetros variam desde milimétricos $(4 \mathrm{~mm})$ a centimétricos $(4 \mathrm{~cm})$, com tamanho médio de $1,5 \mathrm{~cm}$. Apresentam-se predominantemente com formas irregulares (Figuras $2 \mathrm{~d}$ e $2 \mathrm{e}$ ), algumas subarredondadas e mais raramente esféricas. Suas cores são vermel ho-acinzentadas (10R 4/4), geralmente com um córtex milimétrico de cor vermelho-escuro-acizentada (10R 3/6; Figura 2e) e eventualmente bruno-forte (7,5YR 5/8). Esses tons amarelados também estão freqüentemente presentes no interior das glébulas, dispersos em manchas irregulares.

Tais glébulas engl obam a classe dos ferricretes nodulares descritos por Bourman (1993), pelo fato de não apresentarem bordas múltiplas; sendo, portanto, nódul os nas concepções de Brewer (1976) e de Tardy (1993). Correspondem à petroplintita, por constituírem um material rígido (Curi et al., 1993); à fase esquelética da FAO (1994), pelo fato de o material nodular não se apresentar continuamente cimentado, bem como à definição de couraça, conforme critérios apresentados por Tardy (1993).

As glébulas do horizonte Cf são muito duras, quando secas, e muito firmes, quando úmidas, embora possam ser quebradas entre o polegar e o indicador. Suas dimensões variam de 0,3 a 3,0 cm, com diâmetro médio de $1,5 \mathrm{~cm}$. São de cores predominantemente vermelhas (2,5 YR 4/6), com uma borda milimétrica de coloração vermelhoacinzentada (10R 4/4), formas aproximadamente esféricas (geralmente irregulares) e guardam as estruturas morfológicas do arenito. Segundo Roquin et al. (1990) e Tardy \& Roquin (1992), esses ferricretes são imaturos e recebem a adjetivação de litodependentes. Correspondem à rocha ferricretizada deBourman (1993), considerando não sóa preservação das estruturas da rocha de origem e as feições ferruginosas identificadas como plintita, pela menor dureza do material quando comparadas às glébulas do horizonte $F$, mas também a preservação de sua estrutura, quando imersas em água sob agitação suave, conforme indicações de Daniels et al. (1978).

Os atributos morfológicos e os diferentes horizontes do perfil P2 estão apresentados no quadro 2 e na figura 2c. Dois horizontes gl ebulares foram identificados e caracterizados, seguidos aos horizontes texturais. Para os horizonte $\mathrm{F}$ e Cf, a proporção de glébulas em relação à matriz é semelhante à do perfil P1, diferindo na morfologia dos nódulos (tamanho, cor e estrutura).

As petroplintitas são maiores em relação ao $\mathrm{P} 1$; suas dimensões vão desde 0,3 a $10 \mathrm{~cm}$ de diâmetro, com tamanho médio de $2,3 \mathrm{~cm}$. Apresentam formas diversas, predominantemente irregulares e eventual mente arredondadas. Algumas descritas aqui como de estrutura "ruiniformes" (Figura 2f) são as maiores glébulas do horizonte $\mathrm{F}$ e perfazem $10 \%$ do volume deste horizonte. Assemelham-se a um agrupamento ou coesão entre indivíduos menores, pois conseguem, com esforço moderado, individualizar pequenos nódulos na sua periferia, ou mesmo, identificar, nesta massa gl ebular, pequenos volumes com a mesma morfologia das glébulas individuais e 
Quadro 2. Características macromorfológicas dos solos estudados

\begin{tabular}{|c|c|c|c|c|c|c|}
\hline Horizonte & Profundidade & Cor úmida & Textura & Estrutura & Consistência & Observações \\
\hline & $\mathrm{cm}$ & & & & & \\
\hline A & $00-10$ & $7,5 Y R \quad 4 / 2$ & areia-franca & $\begin{array}{l}\text { moderada, pequena e } \\
\text { média, blocos } \\
\text { subangulares }\end{array}$ & $\begin{array}{l}\text { macia, muito friável, } \\
\text { não-plástica e não- } \\
\text { pegajosa }\end{array}$ & $\begin{array}{l}\text { Transição clara e ondulada. } \\
\text { Muito poucos nódul os pequenos, } \\
\text { duros e irregulares }\end{array}$ \\
\hline $\mathrm{E}$ & $10-25$ & $7,5 Y R \quad 4 / 4$ & areia-franca & $\begin{array}{l}\text { fraca, média e grande, } \\
\text { blocos subangulares }\end{array}$ & $\begin{array}{l}\text { ligeiramente dura, } \\
\text { friável, não-plástica } \\
\text { e não-pegajosa }\end{array}$ & $\begin{array}{l}\text { Transição plana e abrupta. } \\
\text { Presç̧a de muito pouco } \\
\text { nódulos, pequenos duros } \\
\text { e irregulares }\end{array}$ \\
\hline $\mathrm{F}$ & $25-45$ & $5 Y R 4 / 6$ & $\begin{array}{l}\text { franco-argilo } \\
\text { arenosa }\end{array}$ & $\begin{array}{l}\text { matriz terrosa maçica } \\
\text { entre as glébulas }\end{array}$ & plástica e pegajosa & $\begin{array}{l}\text { Transição plana e abrupta. } \\
\text { Nódulo dominante, grande e } \\
\text { duro. Presença de cerosidade } \\
\text { no interior dos poros }\end{array}$ \\
\hline Cf & $45-55$ & $5 Y R 4 / 6$ & $\begin{array}{l}\text { franco-argilo } \\
\text { arenosa }\end{array}$ & $\begin{array}{l}\text { matriz terrosa maçica } \\
\text { entre as glébulas }\end{array}$ & plástica e pegajosa & $\begin{array}{l}\text { Transição plana e abrupta. } \\
\text { Nódulos freqüentes, grande e } \\
\text { duro. Cerosidade no interior } \\
\text { dos poros }\end{array}$ \\
\hline $\mathrm{Cr}$ & $55-116$ & 2,5 YR 4/8 & $\begin{array}{l}\text { franco-argilo } \\
\text { arenosa }\end{array}$ & $\begin{array}{l}\text { fragmentos de rocha } \\
\text { entremeado a uma } \\
\text { matriz terrosa maciça }\end{array}$ & $\begin{array}{l}\text { dura, muito firme, } \\
\text { plástica e pegajosa }\end{array}$ & $\begin{array}{l}\text { Cerosidade forte e abundante; } \\
\text { transição gradual e ondulada }\end{array}$ \\
\hline Crgl & $116-140$ & variegada & $\begin{array}{l}\text { franco-argilo } \\
\text { arenosa }\end{array}$ & $\begin{array}{l}\text { fragmentos de rocha } \\
\text { entremeado a uma } \\
\text { matriz terrosa maciça }\end{array}$ & $\begin{array}{l}\text { ligeiramente dura, } \\
\text { firme, plástica e } \\
\text { pegajosa }\end{array}$ & $\begin{array}{l}\text { Cerosidade fraca e comum. } \\
\text { Transição ondulada e gradual. } \\
\text { Ausência de nódulos }\end{array}$ \\
\hline Crg2 & $140-180$ & variegada & areia-franca & $\begin{array}{l}\text { fragmentos de rocha } \\
\text { entremeado a uma } \\
\text { matriz terrosa maciça }\end{array}$ & $\begin{array}{l}\text { ligeiramente dura, } \\
\text { firme, ligeiramente } \\
\text { plástica e ligeiramente } \\
\text { pegajosa }\end{array}$ & $\begin{array}{l}\text { Cerosidade fraca e comum. } \\
\text { Ausência de nódulos }\end{array}$ \\
\hline \multicolumn{7}{|c|}{ Perfil P2 - Argissolo Vermelho-Amarelo eutrófico abrúptico plíntico A moderado textura arenosa/média } \\
\hline A & 00-10 & $7,5 Y R 4 / 2$ & areia-franca & $\begin{array}{l}\text { franca, média, blocos } \\
\text { subangulares }\end{array}$ & $\begin{array}{l}\text { macia, friável, } \\
\text { não-plástica e } \\
\text { não-pegajosa }\end{array}$ & $\begin{array}{l}\text { Transição clara e ondulada. } \\
\text { Presença de muito pouco } \\
\text { nódulos, pequenos, duros e } \\
\text { irregulares }\end{array}$ \\
\hline E & $10-26$ & $7,5 Y R 4 / 4$ & areia-franca & $\begin{array}{l}\text { fraca, média, blocos } \\
\text { subangulares }\end{array}$ & $\begin{array}{l}\text { ligeiramente dura, } \\
\text { friável, não-plástica } \\
\text { e não-pegajosa }\end{array}$ & $\begin{array}{l}\text { Transiç̧ão plana e abrupta. } \\
\text { Nódul os muito pouco, pequenos } \\
\text { e irregulares }\end{array}$ \\
\hline Bt1 & 26-38 & 5YR 4/6 & $\begin{array}{l}\text { franco-argilo } \\
\text { arenosa }\end{array}$ & $\begin{array}{l}\text { moderada, média e } \\
\text { grande, blocos } \\
\text { subangulares }\end{array}$ & $\begin{array}{l}\text { dura, firme, } \\
\text { ligeiramente plástica e } \\
\text { ligeiramente pegajosa }\end{array}$ & $\begin{array}{l}\text { Transiç̧ão plana e gradual. } \\
\text { Nódul os muito pouco, pequenos } \\
\text { e irregulares }\end{array}$ \\
\hline Bt2 & $38-60$ & $5 Y R$ 4/8 & $\begin{array}{l}\text { franco-argilo } \\
\text { arenosa }\end{array}$ & $\begin{array}{l}\text { moderada, média e } \\
\text { grande, blocos } \\
\text { subangulares }\end{array}$ & $\begin{array}{l}\text { dura, firme, plástica } \\
\text { e pegajosa }\end{array}$ & $\begin{array}{l}\text { Transiç̧ão abrupta e ondulada. } \\
\text { Nódul os muito pouco, pequenos } \\
\text { e irregulares }\end{array}$ \\
\hline $\mathrm{F}$ & $60-85$ & $5 Y R 4 / 6$ & $\begin{array}{l}\text { franco-argilo } \\
\text { arenosa }\end{array}$ & matriz maciça & plástica e pegajosa & Transição abrupta e ondulada \\
\hline $\mathrm{Cf}$ & $85-110$ & $5 Y R 4 / 8$ & $\begin{array}{l}\text { franco-argilo } \\
\text { arenosa }\end{array}$ & matriz maciça & plástica e pegajosa & Transição abrupta e ondulada \\
\hline $\mathrm{Cr}$ & $110-164$ & $2,5 Y R \quad 4 / 6$ & $\begin{array}{l}\text { franco-argilo } \\
\text { arenosa }\end{array}$ & $\begin{array}{l}\text { estrutura original da } \\
\text { rocha entremeada a } \\
\text { uma matriz terrosa } \\
\text { maciça }\end{array}$ & $\begin{array}{l}\text { ligeiramente dura, } \\
\text { firme, plástica e } \\
\text { pegajosa }\end{array}$ & $\begin{array}{l}\text { Transição clara e ondulada. } \\
\text { Presença de revestimento } \\
\text { enegrecido de manganês nos } \\
\text { fragmentos do saprolito }\end{array}$ \\
\hline $\mathrm{R}$ & $164-190$ & $2,5 Y R \quad 4 / 6$ & $\begin{array}{l}\text { franco } \\
\text { arenosa }\end{array}$ & estrutura da rocha & $\begin{array}{l}\text { dura, firme, } \\
\text { ligeiramente plástica e } \\
\text { ligeiramente pegajosa }\end{array}$ & $\begin{array}{l}\text { Presença de um revestimento } \\
\text { enegrecido de manganês nas } \\
\text { fraturas e fendas da rocha }\end{array}$ \\
\hline
\end{tabular}

de menores tamanhos, porém fortemente aderidas. Outras poucas petroplintitas, localizadas predominantementena base do horizonte, mostramse enegrecidas no seu interior, evidenciando uma maior segregação de manganês (Coelho, 1998).

O horizonte Cf, semelhante ao do perfil P1, é caracterizado por nódulos que ainda guardam a estrutura da rocha mãe. No entanto, mostram-se maiores, com dimensões que variam desde $0,6 \mathrm{~mm}$ a $7 \mathrm{~cm}$, com diâmetro médio de $3 \mathrm{~cm}$, formas irregulares, algumas com tendências poliédricas cúbicas, assemelhando-se aos fragmentos de saprolito semidecomposto (F igura 2g). Um horizonte saprolítico $\mathrm{Cr}$ ocorre em seguida ao Cf, com a rocha mãe aflorando a $164 \mathrm{~cm}$ de profundidade. 


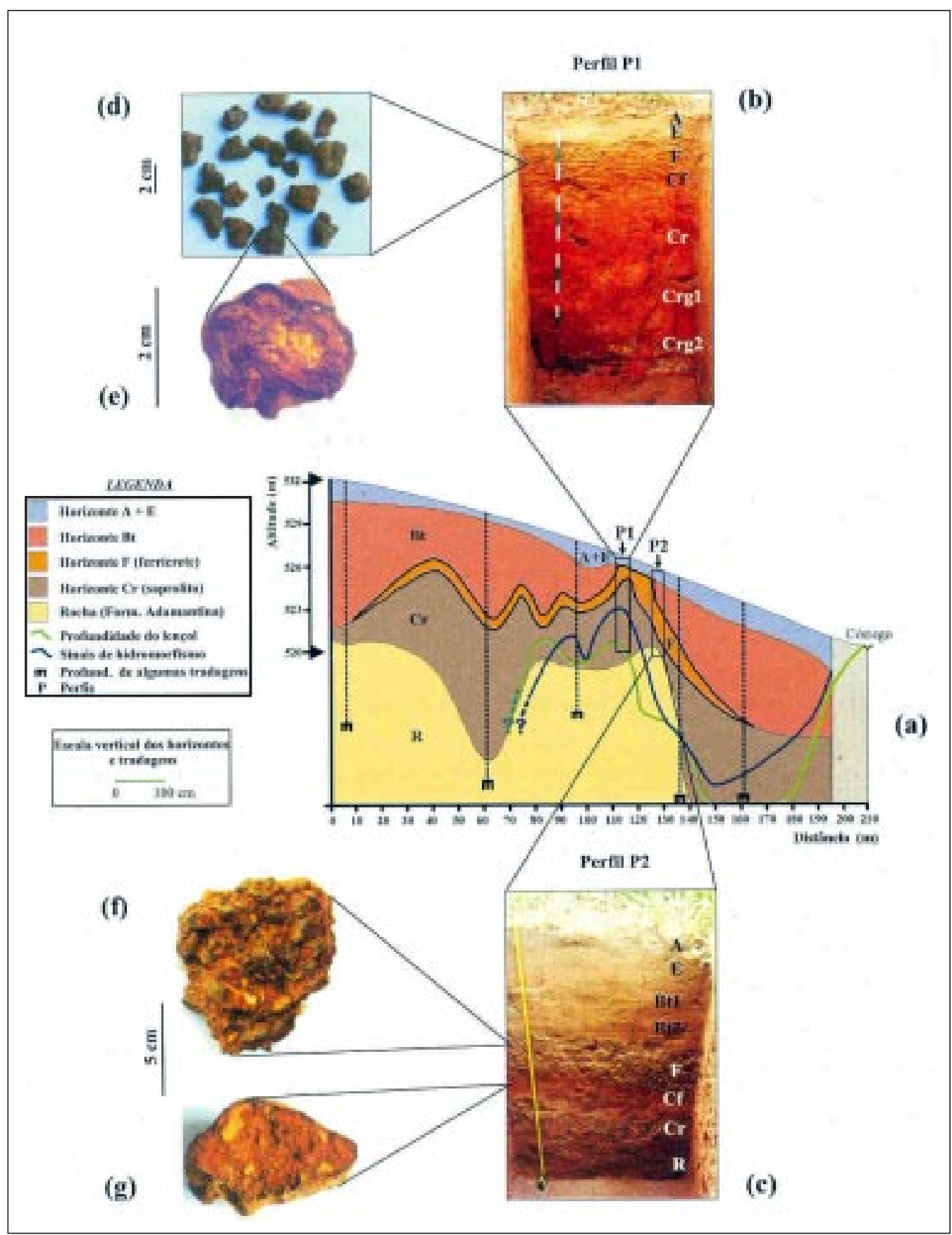

Figura 2. (a) Configuração lateral e vertical dos horizontes na seqüência estudada. Há três escalas no desenho: (a) escala horizontal (x); (b) escala vertical ( $x * 2)$; (c) escala dos horizontes ( $x * 20)$. (b) Perfil P1. (c) Perfil P2. (d) Nódulos predominantes dos horizontes petroplínticos na seqüência estudada. (e) Detalhe do interior dos nódulos, evidenciando o córtex milimétrico mais avermelhado em relação ao seu interior, bem como tons amarelados dispersos na sua matriz. (f) Glébula "ruiniforme" do horizonte petroplíntico (perfil P2). (g) Plintita do horizonte Cr do Perfil P2.

A configuração lateral e vertical dos horizontes na seqüência estudada está representada na figura 2a. É evidente a similaridade entre a configuração lateral da rocha e dos ferricretes. Os sinais de hidromorfismo (matizes com maior val or e baixo croma) nos horizontes saprolíticos distribuem- se de maneira similar aos do nível superior dolençol, verificados três dias após uma chuva intensa. Isso mostra quea rocha exerceu econtinua exercendo forte influência na oscilação do lençol, uma vez queambos os eventos (sinais de hidromorfismo e nível dolençol) acompanham a topografia de al teração da rocha. 
Essa configuração lateral dos horizontes glebulares na seqüência estudada só pode ser explicada pela deposição de ferro no limite superior de oscilação do lençol freático. São os ditos "ferricretes de lençol freático", como sugerem Bourman et al. (1987) e Wright et al. (1992), relacionados com a lixiviação do ferro ferroso da paisagem a montantee deposi ção na zona de vadosa, onde condições mais oxidantes prevalecem.

Outras características morfológicas evidenciam a designação de "ferricrete de lençol" aos materiais aqui estudados. Comparado a um perfil laterítico típico (McFarlane, 1976, 1983), o pequeno desenvolvimento dos perfis estudados revela uma origem de lençol ao ferricrete, como comentam McFarlane (1976, 1983) e Wright et al. (1992). Também as concentrações de ferro nos solos, originando os ferricretes pedogenéticos, são tipicamente complexos, tanto estrutural como composicionalmente (Tardy \& Nahon, 1985; Milnes et al., 1985). Todavia, as glébulas aqui são simples em estrutura, como descritas anteriormente e verificadas nas observações micromorfológicas, corroborando novamente sua origem associada à zona de vadosa. Acredita-se que a presença dos ferricretes apenas no sopé da vertente da área estudada seja a principal evidência da lixiviação e mobilização do ferro ferroso das paisagens a montante e deposi ção no estreito limite de oscilação do lençol freático.

\section{Micromorfologia}

A análise dos horizontes saprolíticos do perfil P1 (Quadro 3) evidencia a dominância de uma trama porfírica aberta no Crg2, com tendências gefúricas locais, as quais evoluem para uma trama exclusivamente porfírica fechada no horizonte $\mathrm{Cr}$, acarretandoacentuada redução da porosi dade (passa de $40 \%$, no $\mathrm{Crg} 2$, para $10 \%$, no $\mathrm{Cr}$ ). Além dessa variação, o surgimento de cutãs no $\mathrm{Cr}$, bem como de um plasma isótico associado a uma estrutura de base silassépica, evidencia e corrobora a partici pação da argiluviação no aumento de argila nesse horizonte, tal como relatado nas observações de campo.

\section{Quadro 3. Características micromorfológicas dos solos estudados}

\begin{tabular}{|c|c|c|c|c|}
\hline \multirow{3}{*}{ Atributo } & \multicolumn{4}{|c|}{ Perfil P1 - Plintossolo Pétrico concrecionário distrófico típico A moderado textura arenosa/média esquelética } \\
\hline & \multicolumn{4}{|c|}{ Horizonte/profundidade de coleta } \\
\hline & E/F 1 (18-28 cm) & $\mathrm{F} 2 / \mathrm{Cr}(50-65 \mathrm{~cm})$ & $\operatorname{Cr}(100-110 \mathrm{~cm})$ & Crg2 $(145-160 \mathrm{~cm})$ \\
\hline Plasma & $\begin{array}{l}20 \% \text {, bruno-escuro, argila } \\
\text { mineralógica e óxidos de ferro, } \\
\text { isótico passando para } \\
\text { vermel ho-amarelado, silas- } \\
\text { sépica com tendência } \\
\text { vossemassépica próximo ao F } 1 .\end{array}$ & $\begin{array}{l}20 \% \text {, vermel ho-amarelado } \\
\text { predominante e localmente } \\
\text { vermelho-escuro e vermel ho, } \\
\text { argila mineralógica e óxidos de } \\
\text { ferro isótico com tendência } \\
\text { vossemassépica. }\end{array}$ & $\begin{array}{l}\text { 25\%, vermel ho-amarelo } \\
\text { predominante e localmente } \\
\text { vermelho-escuro e vermel ho, } \\
\text { argila mineralógica e óxidos de } \\
\text { ferro, plasma silassépico com } \\
\text { tendência vossemassépica. }\end{array}$ & $\begin{array}{l}20 \% \text {, vermelho-amarelo, } \\
\text { silassépico e raramente } \\
\text { vossépico, argila mineralógica } \\
\text { e óxidos de ferro. }\end{array}$ \\
\hline Esqueleto & $\begin{array}{l}40 \% \text {, quartzo subarredondado } \\
\text { nas frações grosseiras } \\
\text { enquanto as frações finas são } \\
\text { subangulares, paredes lisas } \\
\text { e presença de alguns } \\
\text { feldspatos potássicos. }\end{array}$ & $\begin{array}{l}30 \% \text {, quartzo com a mesma } \\
\text { forma e exoscopia do horizonte } \\
\text { anterior, apresenta alguns } \\
\text { campos sel ecionados com grãos } \\
\text { finos devido a atividade } \\
\text { biológica e a própria litologia. }\end{array}$ & $\begin{array}{l}65 \% \text {, quartzo com a mesma } \\
\text { forma e exoscopia dos } \\
\text { horizontes anteriores, no } \\
\text { entanto, havendo um } \\
\text { aumento dos grãos muito } \\
\text { finos. }\end{array}$ & $\begin{array}{l}40 \% \text {, quartzo semel hante } \\
\text { quanto a forma e exoscopia } \\
\text { aos horizontes acima, variando } \\
\text { em granulometria (predomina } \\
\text { fração mais grosseira, } 350 \mu \mathrm{m} \text { ) } \\
\text { e maior abundância de } \\
\text { feldspatos potássicos ( } 2 \%) \text {. } \\
\text { Algumas porções da fábrica } \\
\text { interna são dominadas por } \\
\text { esqueleto triado na fração } \\
\text { areia fina. }\end{array}$ \\
\hline Poros & $\begin{array}{l}40 \% \text {, predomínio de poros de } \\
\text { arranjamento e ortocavidades } \\
\text { no E, enquanto no } F 1 \text {, canais, } \\
\text { orto e metacavidades. }\end{array}$ & $\begin{array}{l}50 \% \text {, ortocavidades } \\
\text { predominante, algumas meta, } \\
\text { poucos canais e alguma } \\
\text { porosidade de arranjamento. }\end{array}$ & $\begin{array}{l}10 \% \text {, reduziu sensivel mente } \\
\text { em relação a transição F } 2 / C r \text {, } \\
\text { predominando ortocavidades } \\
\text { e canais irregulares. }\end{array}$ & $\begin{array}{l}40 \% \text {, ortocavidades e canais } \\
\text { irregulares, poucas fissuras. }\end{array}$ \\
\hline Trama & $\begin{array}{l}\text { Gefúrica com tendência } \\
\text { chitônica no E, passando para } \\
\text { porfírica fechada no } \mathrm{F} 1 \text {. }\end{array}$ & $\begin{array}{l}\text { Porfírica com tendência } \\
\text { gefúrica localmente. }\end{array}$ & Porfírica fechada. & $\begin{array}{l}\text { Porfírica fechada com } \\
\text { tendência gefúrica localmente. }\end{array}$ \\
\hline Feições & $\begin{array}{l}\text { Nódulos isóticos ( } 40 \% \text { da } \\
\text { lâmina), ferriargilãs, hematãs, } \\
\text { cutãs de tensão no F 1, } \\
\text { enquanto no E predominam } \\
\text { isotúbulos. }\end{array}$ & $\begin{array}{l}\text { Nódulos ocupam } 60 \% \text { do } \\
\text { plano da lâmina, ferriargilãs, } \\
\text { cutãs de transformação e } \\
\text { hematãs. Cutãs perfazem } \\
10 \% \text { do plasma. }\end{array}$ & $\begin{array}{l}\text { Cutãs ocupam } 20 \% \text { do } \\
\text { plasma e correspondem a } \\
\text { ferriargilãs de iluviação, cutãs } \\
\text { de transformação e hematãs. } \\
\text { Também isotúbulos mostram- } \\
\text { se presentes em } 20 \% \text { da lâmina, } \\
\text { geralmente circulares e com } \\
\text { esquel eto triado. }\end{array}$ & $\begin{array}{l}\text { Poucos cutãs (1\%), } \\
\text { predominando de } \\
\text { transformação. Presença } \\
\text { de isotúbulos circulares. }\end{array}$ \\
\hline
\end{tabular}


Quadro 3, Continuação

\begin{tabular}{|c|c|c|c|c|c|c|c|}
\hline \multirow{3}{*}{ Atributo } & \multicolumn{7}{|c|}{ Perfil P2 - Argissolo Vermelho-Amarelo eutrófico abrúptico plíntico A moderado textura arenosa/média } \\
\hline & \multicolumn{7}{|c|}{ Horizonte/profundidade de coleta } \\
\hline & $E(12-22 \mathrm{~cm})$ & E/Bt1 (20-30 cm) & Bt2/F $1(55-70 \mathrm{~cm})$ & $F 1(65-75 \mathrm{~cm})$ & F $2 / \mathrm{Cr}(105-120 \mathrm{~cm})$ & $\operatorname{Cr}(140-150 \mathrm{~cm})$ & $R(175-185 \mathrm{~cm})$ \\
\hline Plasma & $\begin{array}{l}5 \% \text {, bruno, } \\
\text { argila } \\
\text { mineralógica e } \\
\text { óxidos de ferro, } \\
\text { isótico }\end{array}$ & $\begin{array}{l}20 \% \text {, bruno- } \\
\text { escuro, argila } \\
\text { mineralógica e } \\
\text { óxidos de ferro, } \\
\text { isótico. }\end{array}$ & $\begin{array}{l}30 \% \text {, vermelho- } \\
\text { amarelo } \\
\text { predominante e } \\
\text { localmente } \\
\text { vermelho-escuro } \\
\text { e vermelho, } \\
\text { argila } \\
\text { mineralógica e } \\
\text { óxidos de ferro. } \\
\text { Fundo matricial } \\
\text { isótico com } \\
\text { tendência } \\
\text { massépica. }\end{array}$ & $\begin{array}{l}35 \% \text {, vermelho- } \\
\text { amarelo } \\
\text { predominante e } \\
\text { localmente } \\
\text { vermelho-escuro } \\
\text { e vermelho, } \\
\text { argila } \\
\text { mineralógica e } \\
\text { óxidos de ferro. } \\
\text { Fundo matricial } \\
\text { isótico com } \\
\text { tendência } \\
\text { vossemassépico. }\end{array}$ & $\begin{array}{l}20 \% \text {, vermelho- } \\
\text { amarelo, argila } \\
\text { mineralógica e } \\
\text { óxidos de ferro, } \\
\text { silassépico e } \\
\text { localmente } \\
\text { vossemassépico. }\end{array}$ & $\begin{array}{l}35 \%, \\
\text { predominante- } \\
\text { mente vermelho, } \\
\text { com alguns } \\
\text { domínios } \\
\text { vermelho- } \\
\text { escuro- } \\
\text { acinzentado } \\
\text { (5\%), argila } \\
\text { mineralógica e } \\
\text { óxidos de ferro e } \\
\text { manganês, } \\
\text { isótico e } \\
\text { localmente } \\
\text { silassépico. }\end{array}$ & $\begin{array}{l}40 \% \text {, } \\
\text { predominante- } \\
\text { mente vermelho } \\
\text { com alguns } \\
\text { domínios } \\
\text { vermelho- } \\
\text { escuro- } \\
\text { acinzentado } \\
\text { devido a maior } \\
\text { segregação do } \\
\text { ferro e } \\
\text { manganês, } \\
\text { argila } \\
\text { mineralógica e } \\
\text { óxidos de ferro e } \\
\text { manganês. } \\
\text { Isótico }\end{array}$ \\
\hline Esqueleto & $\begin{array}{l}45 \% \text {, quartzo } \\
\text { subarredondado } \\
\text { nas frações } \\
\text { grosseiras e } \\
\text { subangulares } \\
\text { nas mais finas. } \\
\text { Tamanho } \\
\text { dominante } \\
200 \mu \text { m. } \\
\text { Presença de } \\
\text { feldspatos } \\
\text { (raros) }\end{array}$ & $\begin{array}{l}35 \% \text {, idem } \\
\text { anterior }\end{array}$ & $55 \%$, idem & $55 \%$, idem & $\begin{array}{l}30 \% \text {, idem, porém } \\
\text { com maiores } \\
\text { conteúdos de } \\
\text { fel dspatos } \\
\text { potássicos e } \\
\text { aumento do } \\
\text { tamanho médio do } \\
\text { grão } \\
(300 \mu \mathrm{m})\end{array}$ & $\begin{array}{l}45 \% \text {, quartzo } \\
\text { subarredondado } \\
\text { nas frações areia } \\
\text { média e fina e } \\
\text { subangular na } \\
\text { fração muito } \\
\text { fina. Tamanho } \\
\text { médio do grão: } \\
300 \mu \text { m. } \\
\text { Algumas porções } \\
\text { predominam } \\
\text { quartzo fino. }\end{array}$ & $\begin{array}{l}55 \% \text {, idem } \\
\text { anterior, com } \\
\text { maior } \\
\text { participação de } \\
\text { feldspatos, } \\
\text { ocupando } 5 \text { a } 8 \% \\
\text { do fundo } \\
\text { matricial. } \\
\text { Alguns domínios } \\
\text { são ocupados } \\
\text { com quartzo } \\
\text { na fração areia } \\
\text { muito fina. }\end{array}$ \\
\hline Poros & $\begin{array}{l}50 \% \text {, } \\
\text { predomínio de } \\
\text { uma porosidade } \\
\text { de arranjo e } \\
\text { ortocavidades. }\end{array}$ & $\begin{array}{l}45 \% \text {, predomínio } \\
\text { de ortocavidades } \\
\text { e poros de } \\
\text { arranjo }\end{array}$ & $\begin{array}{l}15 \% \text {, predomínio } \\
\text { de orto e } \\
\text { metacavidades } \\
\text { e canais }\end{array}$ & $\begin{array}{l}\text { 10\%, predomínio } \\
\text { de orto e } \\
\text { metacavidades } \\
\text { e canais }\end{array}$ & $\begin{array}{l}50 \% \text {, predominam } \\
\text { ortocavidades. No } \\
\text { entanto, } \\
\text { metacavidades e } \\
\text { orto e meta canais } \\
\text { estão presentes. }\end{array}$ & $\begin{array}{l}20 \% \text {, predomínio } \\
\text { de ortocavidades } \\
\text { e algumas } \\
\text { fissuras. }\end{array}$ & $\begin{array}{l}5 \% \\
\text { predominante- } \\
\text { mente fissurais }\end{array}$ \\
\hline Trama & Chitônica. & $\begin{array}{l}\text { Porfírica no Bt, } \\
\text { passando a } \\
\text { gefúrica e } \\
\text { chitônica nas } \\
\text { proximidades } \\
\text { do E }\end{array}$ & Porfírica fechada. & $\begin{array}{l}\text { Predomina } \\
\text { porfírica fechada } \\
\text { com restrita } \\
\text { porosidade, } \\
\text { alternadas com } \\
\text { porfírica aberta } \\
\text { de maior } \\
\text { porosidade }\end{array}$ & $\begin{array}{l}\text { Porfírica com } \\
\text { tendência gefúrica } \\
\text { localmente. }\end{array}$ & Porfírica fechada & Porfírica fechada \\
\hline Feições & $\begin{array}{l}\text { Presença de } \\
\text { nódulos isóticos } \\
\text { milimétricos } \\
(0,3 \mathrm{~cm}) \text { e } \\
\text { agrotúbulos } \\
\text { circulares } \\
\text { formados por } \\
\text { raízes. }\end{array}$ & $\begin{array}{l}\text { Presença de } \\
\text { nódulos isóticos } \\
\text { milimétricos } \\
(0,3 \text { mm). Raros } \\
\text { ferriargilãs de } \\
\text { iluviação. } \\
\text { Presença de } \\
\text { agrotúbulos } \\
\text { circulares } \\
\text { formados por } \\
\text { raízes }\end{array}$ & $\begin{array}{l}\text { Aumento do } \\
\text { tamanho e } \\
\text { quantidade dos } \\
\text { nódulos isóticos. } \\
\text { Presença de } \\
\text { ferriargilãs e } \\
\text { hematãs em } \\
\text { pequenas } \\
\text { quantidades } \\
\text { (1\% do plasma) }\end{array}$ & $\begin{array}{l}\text { Nódulos ocupam } \\
60 \% \text { da lâmina. } \\
\text { Presença de } \\
\text { ferriargilãs } \\
\text { simples, cutãs } \\
\text { zonados } \\
\text { complexos e } \\
\text { hematãs. } \\
\text { Presença de } \\
\text { isotúbulos } \\
\text { circulares. }\end{array}$ & $\begin{array}{l}\text { Nódulos } \\
\text { irregulares } \\
\text { ocupam 30\% do } \\
\text { plano da lâmina. } \\
\text { Presença de } \\
\text { ferriargilãs de } \\
\text { iluviação } \\
\text { (3\% do plasma), } \\
\text { cutãs de } \\
\text { transformação ( } 2 \% \\
\text { do plasma)e } \\
\text { hematãs (<1\%) }\end{array}$ & $\begin{array}{l}\text { Nódulos } \\
\text { milimétricos e } \\
\text { subarredondado } \\
\text { s ocupando 5\% } \\
\text { da lâmina. } \\
\text { Poucos } \\
\text { ferriargilãs de } \\
\text { iluviaçãa. } \\
\text { Dominância de } \\
\text { hematãs. } \\
\text { Presença de } \\
\text { isotúbulos circu- } \\
\text { lares. }\end{array}$ & $\begin{array}{l}\text { Presença de } \\
\text { neomangãs e } \\
\text { quasimangãs, } \\
\text { neoferrãs e } \\
\text { quasiferrãs. }\end{array}$ \\
\hline
\end{tabular}

Para ilustrar essemecanismo, a figura 3a mostra o fundo matricial do horizonte Cr. Observa-se uma trama porfírica fechada em que poros ortocavitários e canais, em pequeno número, juntamente com a intensa ocorrência de ferriargilãs de iluviação e hematãs, evidenciam as mobilizações de Fee argila no horizonte, possivelmente provindos da matriz interglebular. Assim, ferroeargila estão preenchendo a porosidade cavitária, reduzindo-a nesta porção do perfil, sendo responsáveis pel o acentuado acréscimo da fração argila em relação aos demais horizontes inferiores do perfil. A figura 3b revela, em detal hes, 
os ferriargilãs identificados na figura anterior. A parentemente o ferro está segregado em algumas porções do cutã, apresentando-se isótico sob nicóis cruzados, sugerindo mobilização deF $\mathrm{e}^{2+}$ posterior à deposição cutânica, difundindo-se e preci pitando-se nos poros de menor tamanho na forma de hematita, tal comosugerido por Nahon (1986) eTardy \& Nahon (1985). Observa-se, também, pelo exame da figura $3 \mathrm{~b}$, a presença de esquel eto muito fino incorporado ao ferriargilã. Essefato evidencia a mobilização a curta distância dequartzo muito fino, preenchendo a porosidade cavitária juntamente com a argila iluviada. Mecanismossimilares foram descritos por Nahon (1986).

A transição $\mathrm{Cf} / \mathrm{Cr}$ é marcada por um acréscimo acentuado da porosidade cavitária em relação ao horizonte $\mathrm{Cr}$ (passa de 10\%, no $\mathrm{Cr}$, para $50 \%$, na transição $\mathrm{Cf} / \mathrm{Cr}$ ), possivelmente relacionado com fluxos hídricos turbulentos durante as oscilações do lençol freático. As seções delgadas no topo do horizonte $\mathrm{Cr}$ mostraram a presença de ortocavidades de $1 \mathrm{~mm}$ de diâmetro em estádios de desmantelamento, promovendo a coalescência desses poros e a degradação dos agregados porfíricos. A maior concentração de quartzo nas frações areia muito fina e fina, associada a alguns poros, evidencia uma possível dissolução dos grãos de esqueleto e um estado geral de desmonte da estrutura nessas porções do perfil.

A significativa porosidade gerada imediatamente abaixo do horizonte plíntico e a disponi bilização dos elementos provindos da degradação das glébulas, fato que será relatado posteriormente, possi bilitaram a mobilização de $\mathrm{Fe}^{2+}$ do horizonte ferricrete, bem como da argila e de frações mais grosseiras, os quais foram depositados no horizonte $\mathrm{Cr}$ (Figura $3 b$ ).

O perfil P2 (Quadro 3) assemelha-se ao P1 em relação às características micromorfológicas e aos mecanismos envolvidos na gênese dos horizontes ferricretes. Nele, além das glébulas, pedotúbulos e ferriargilãs constituem as feições pedológicas do fundo matricial interglebular. Esses últimos ocupam aproximadamente $5 \%$ do total de plasma e, muitas vezes, mostram-se intensamenteferruginizados, ora assemel hando-se a ferriargilãs microlaminados parcialmente isóticos, ora a hematãs, com sua orientação forte e contínua totalmente obliterada pela ferruginização. A figura 4 mostra, em detal he, esses dois tipos de cutãs e sugere uma origem comum, uma vez que apenas o grau deferruginização os diferencia. Possivelmente, o ferro, difundido e preci pitado no interior dos ferriargilãs de iluviação, origina o caráter isótico mostrado na figura 4, constituindo uma das etapas iniciais de formação dos nódul os ferruginosos.

\section{Glébulas}

As glébulas, em sua maioria, mostram-seirregulares quantoà morfologia externa, sem formas definidas. Segundo Brewer (1976), essa morfologia é indício de uma origem in situ. Quanto à individualização,

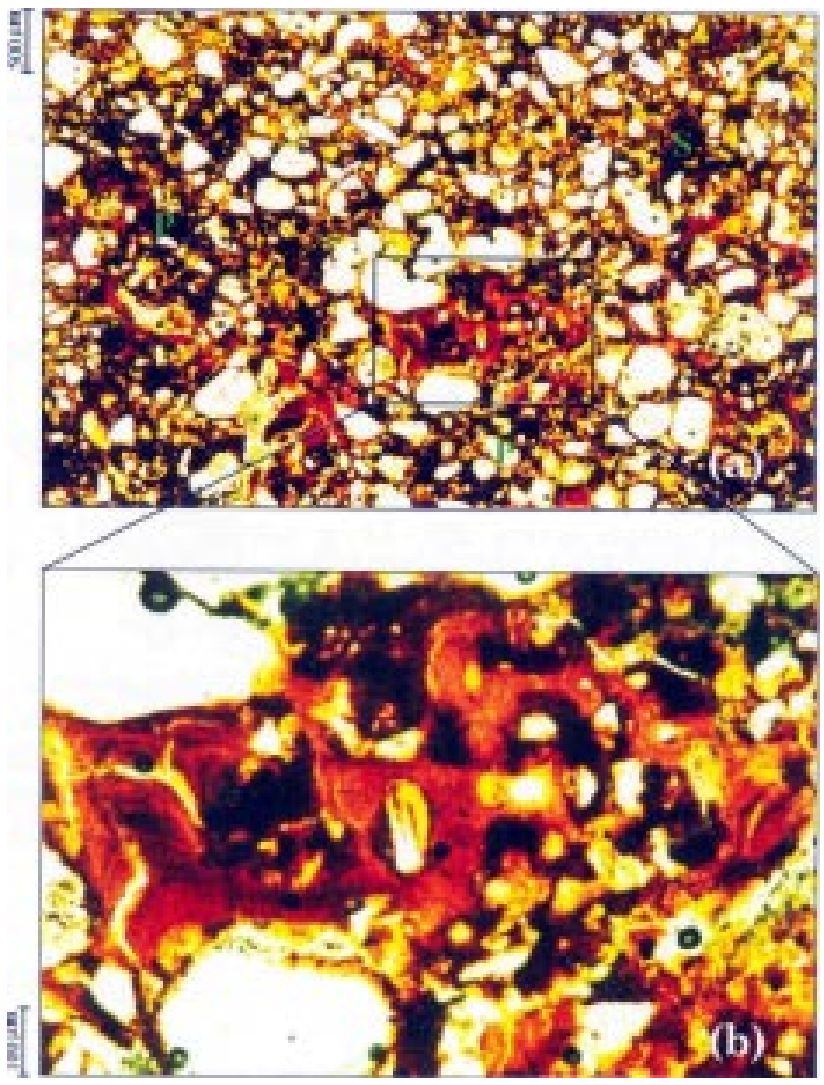

Figura 3. (a) Vista geral do horizonte $\mathrm{Cr}$ do perfil P1. Nota-se a deposição de ferriargilãs na porosidade gerada entre os fragmentos de saprolito (P) e o solo (S). Luz nomal - 2,5x. (b) Detalhes do ferriargilã da figura 3a. A incorporação de grãos de quartzo muito fino no preenchimento sugere sua movimentação à curta distância, juntamente com a argiluviação. Luz normal - 10x.

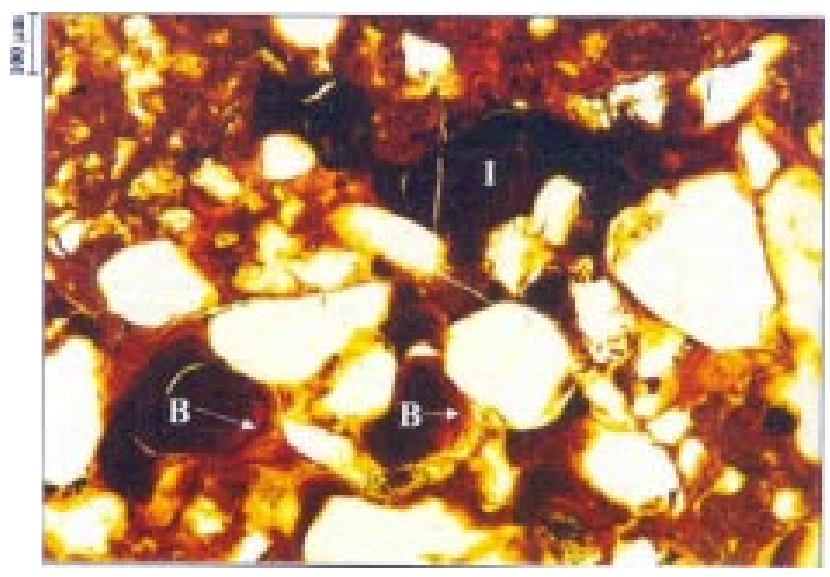

Figura 4. Ferriargilãs de iluviação no fundo matricial interglebular do horizonte F (perfil P2). Notamse os bandeamentos no cutã parcialmente isótico (B) sob luz natural e a completa isotropia do cutã acima (I). Luz normal - 10x. 
apresentam limites muito nítidos em relação ao fundo matricial interglebular, caracterizando-as como discretas e fracamente aderentes.

Não há diferenças entre as glébulas plínticas e petroplínticas quanto à morfologia externa, bem como entre as glébulas dos diferentes perfis. Internamente, classificam-se como indiferenciadas (Brewer, 1976). No entanto, $40 \%$ das glébulas petroplínticas mostram um córtex deaproximadamente 0,15 mm e de col oração marrom ou amarelada, e que estão ausentes nas plínticas, o queserá di scutido posteriormente. Além dessa diferença, algumas plintitas não são completamente isóticas e apresentam porções anisotrópicas no seu interior, associadas a col orações mais amareladas. As figuras 5 e 6 evidenciam essa diferença, salientando a presença de porções mais claras em algumas glébulas plínticas, anisotrópicas sob microscópio óptico e de col orações amarel adas, possivel mente relacionadas com seu mai or teor de goethita.

Apesar de classificá-las como indiferenciadas, o que significa afirmar que seus constituintes não apresentam uma orientação específica, as glébulas (aproximadamente 70\%) examinadas no plano das lâminas mostram domínios ou volumes internos ocupados por esquel eto de diferente granulometria em relação ao restante da glébula, ou por apenas plasma.

Também é bastante comum a ocorrência de glébulas inteiras com granulometria interna dominada por esqueleto na fração areia muito fina (100 $\mu \mathrm{m})$, enquanto, em glébulas vizinhas e muito próximas, bem como em sua matriz intergl ebular, o esquel eto está concentrado predominantemente na fraçãoareia média (200 $\mu \mathrm{m}$ ) (F iguras 7 e 8). Glébulas com um fundo matricial de diferentes granulometrias do esqueleto também são freqüentes no plano da lâmina. Segundo Brewer (1976), todas essas feições ferruginosas aqui descritas são enquadradas como nódulos em virtude de sua fábrica interna indiferenciada.

Da descrição micromorfol ógica desses materiais, podem-se inferir alguns mecanismos envolvidos na sua gênese. Nódulos com o esquel eto triado e de diferentes granulometrias desenvolvidos Iado a lado no horizonteferricrete, equetambém diferem do fundo matricial interglebular (Figura 8), podem sugerir uma origem detrital ou alóctone a esses materiais.

Brewer (1976) propõe que se observe o contraste entre o material da fábrica interna das glébulas e o seu entorno. Quando são diferentes, o autor classifica-os como anórtico e afirma serem esses nódulos alóctones, ou seja, sua gêneseestá associada à formação em pedoambientes diferenciados, e que, por transporte e deposição, originam feições com diferentes fábricas internas em relação ao fundo matricial interglebular. No entanto, essa hipótese aparentemente não é válida para a gênese dos ferricretes aqui estudados, uma vez que existem evidências de sua origem autóctone.
Diferentes mecanismos podem estar associados à seleção do quartzo ou à redução de sua granulometria no solo e no saprol ito. A origem litogenética relacionada com o próprio ambiente deposicional da rocha pode estar condicionando domínios ocupados com quartzo mais fino nos diferentes horizontes ou camadas dos perfis, tal como foram observados na rocha e no saprolito do perfil P2.

Outro mecanismo refere-se à iluviação conjunta de plasma e esqueleto fino a curtas distâncias, tal como evidenciado anteriormente, os quais são depositados nos macroporos e, posteriormente, incorporados ao nódulo durante a sua formação. Também, a dissolução do quartzo nos pedoambientes de maior fluxo hídrico pode ser responsável pela redução de seu tamanho.

Finalmente, pode-se admitir que a atividade biológica exerça um controle efetivo na morfologia interna de algumas glébulas milimétricas e que apresentem esqueleto triado em relação ao fundo matricial interglebular. A figura 9 mostra uma glébula plíntica em formação (horizonte Cr, perfil P2) com grãos de esqueleto de maiores dimensões al inhados e separando uma porção com quartzo fino deoutra, com esquel eto de diferentes granulometrias. Isso revela a existência de um pedotúbulo que foi incorporado ao fundo matricial e, posteriormente, ferruginizado durante a gênese das glébulas. I números isotúbulos foram identificados em todos os horizontes dos perfis, vários del es com esquel eto triado e de pequenas dimensões.

A presença de domínios ocupados apenas com plasma no interior das glébulas mostra a participação dos mecanismos de iluviação na sua formação. Conforme observado por vári os autores, o desenvolvimento de uma macroporosidade no saprolito é acompanhado pelo seu preenchimento com argila secundária ou proveniente da argiluviação. Esses processos caracterizam as etapas iniciais na formação de nódulos e concreções ferruginosas (Bellinfante et al., 1970; Nahon, 1986) eaparentam ser procedentes nas glébulas estudadas. A figura 10 evidencia a influência da atividade biológica e a iluviação na formação dos nódulos. Notam-se alguns volumes dominados apenas por plasma (P), enquanto outros formam verdadeiros "corredores" (C) preenchidos com um fino esquel eto triado e plasma. Possivelmente, esses "corredores" são paleopedotúbulos, enquanto os domínios ocupados com plasma apenas correspondem a canais biológicos, que foram posteriormente preenchidos com ferriargilãs ou hematãs e ferruginizados durante a gênese das glébulas. Pode-se especular ainda que tal ferruginização poderia completar-se por uma colmatação da macroporosidade com géis de ferro, favorecendo a difusão do el emento para a matriz vizinha, o que explicaria a similaridadeentre o esquel eto encontrado nas bordas de algumas glébulas e o da matriz do sol o circundante. 


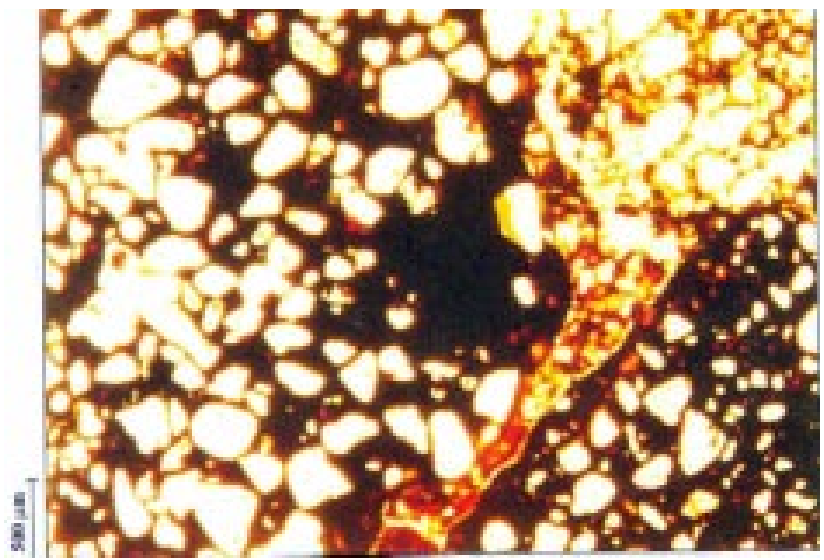

Figura 5. Morfologia interna da petroplintita do horizonte F (perfil P2) evidenciando seu completo caráter isótico. Luz normal - 2,5x.

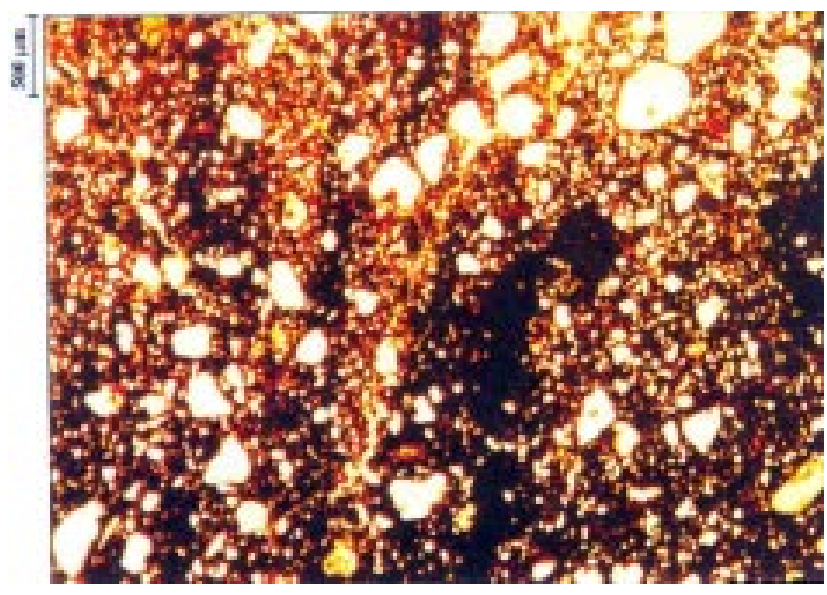

Figura 6. Morfologia interna da plintita do horizonte Cf (perfil P1) mostrando volumes mais claros relacionados com as porções amareladas e anisotrópicas sob microscópio ótico. Luz normal - 2,5x.

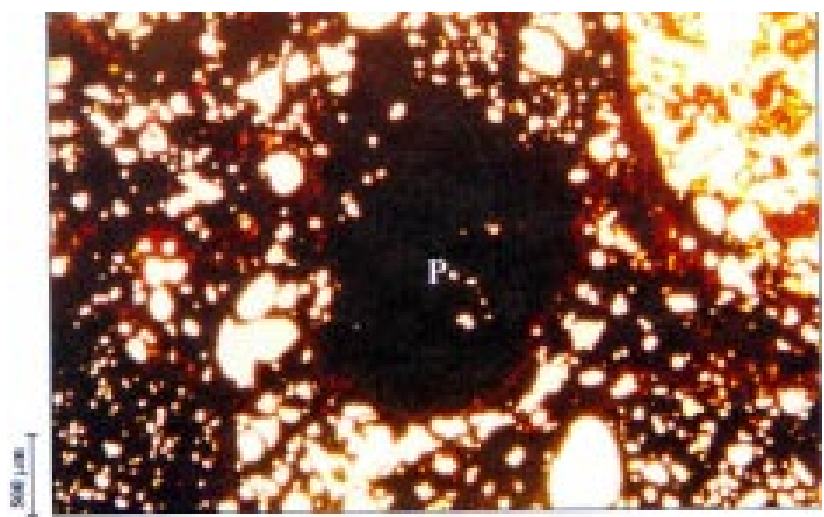

Figura 7. Petroplintita do perfil P1 mostrando parte de seu volume interno predominantemente plásmico (P). Luz normal - 2,5x.

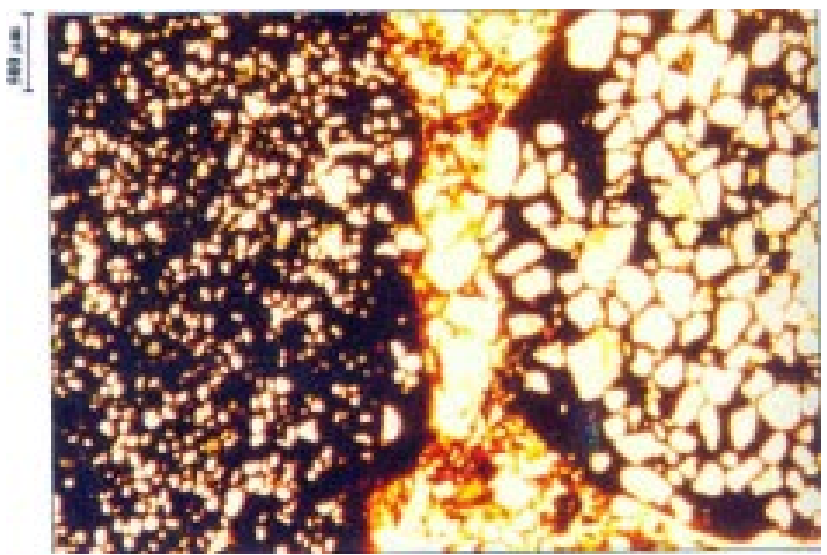

Figura 8. Fotomicrografia mostrando glébulas com diferentes granulometrias do esqueleto presentes lado a lado no horizonte petroplíntico do perfil P2. Luz normal - 2,5x.

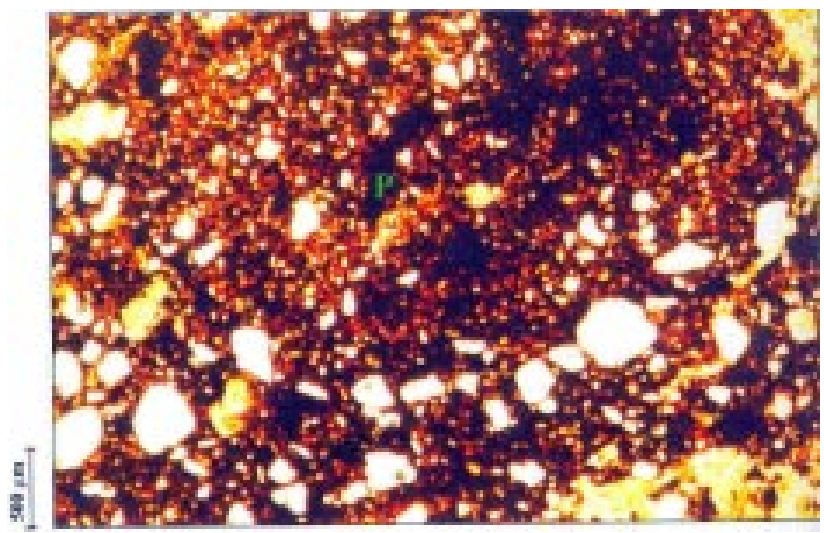

Figura 9. Plintita do perfil P2 evidenciando sua origem associada à atividade biológica. Nota-se o alinhamento dos grãos de esqueleto separando os volumes com quartzo mais fino daqueles de maiores dimensões. 0 domínio com esqueleto fino corresponde a um pedotúbulo $(P)$, o qual se encontra ferruginizado. Luz normal - 2,5x.

\section{Gênese das glébulas "ruiniformes"}

As glébulas identificadas como "ruiniformes" correspondem às de mai ores di mensões encontradas nos horizontes ferricretes; aparentemente, assemel ham-se a uma fusão entre glébulas individuais. As evidências micromorfológicas confirmam essa suposição e sugerem a partici pação deaportes de $\mathrm{Fe}^{2+}$ nos estádios finais ou posteriores à sua formação, difundindo-se e promovendo a cimentação entre as glébulas individuais, tal como sugerido por Sivarajasingham et al. (1962) e McFarlane (1976). A figura 11 evidencia essas interpretações. N ota-se que a fusão entre as gl ébulas dá-se por uma "ponte" de constituição diferente em 
relação ao fundo matricial intraglebular. Essa diferença é evidente no esquel eto, de dimensões superiores às das glébulas. Isso sugereuma formação em diferentes épocas para as "pontes" e as glébulas, pois, caso fossem sincrônicas, assemel har-se-iam na granulometria do esquel eto.

A fotomicrografia da figura 11 correspondea uma glébula ruiniforme do horizonte petroplíntico (perfil P2), sendo que todos os pontos de fusão ("pontes") interglebulares observados no plano da lâmina mostram a mesma morfologia, ou seja, quartzo de granulometria diferente ao do fundo matricial intraglebular eassemel hando-se à matriz interglebular.

O fundo matricial da matriz friável entre essas glébulas é pouco poroso, compacto, mostrando apenas poucas ortocavidades (menos que $10 \%$ ). Muitos domínios são isóticos, evidenciando a presença de hematãs euma fortesegregação doferro. Possivelmente, constituem ambientes mais confinados e, portanto, mais preservados dos processos de intemperismo, em que as mobilizações no seu interior são menos influenciadas, ou mesmo, pouco influenciam o horizonte petroplíntico como um todo. Essas glébulas não mostram um córtex goethítico de degradação; no entanto, a presença freqüente de fraturas entre a "ponte" e as glébulas (Figura 11) mostra que sua estrutura encontra-se em estádios iniciais de desmantelamento, liberando glébulas individuais ao horizonte petroplíntico eretornando, assim, às suas condições iniciais de formação.

\section{Degradação e formação dos ferricretes}

Couraças nodulares em estádio de desmantel amento originam os chamados pisolitos de degradação, caracterizados pela presença de córtex goethítico (Tardy, 1993). Segundo Beauvais \& Colin (1993), correspondem ao último estádi o de desenvolvimento dos ferricretes, onde se desenvolve um córtex marrom ou uma trama no entorno ou dentro dos nódul os hematíticos. As figuras 12 e 13 evidenciam essas feições de dissol ução.

Sob mi croscópio ótico, essas glébulas petroplínticas mostram uma coloração predominantemente amarel ada no córtex, sugerindo di ssol ução eremoção de hematita, favorecendo a presença de goethita, a qual pode ser incorporada ao fundo matricial interglebular e contribuir para a pedogênese do solum sobrejacente durante a evolução dos perfis. Aproximadamente $40 \%$ das petroplintitas observadas no plano das lâminas mostram essas feições, caracterizando o estádio incipiente de desmantel amento da couraça. Esse fatoleva a pensar que as condições atuais divergem daquelas responsáveis pela gênese dos ferricretes no passado.

Podem-se atribuir essas diferenças a dois possíveis fatores, que devem estar associados ao clima ou à litologia da Formação Adamantina. I nicialmente, pode-se imaginar que os horizontes petroplínticos tiveram sua origem em climas pretéritos, em condições paleoclimáticas mais contrastantes do queas atuais, provavel mente mais quentes, com estações bem definidas e um período seco prolongado, fatores esses fortemente apregoados, por muitos autores, como uma condição sinequa non na evolução das couraças ferrugi nosas (Sivarajasingham et al., 1962; Tardy et al., 1991). Outra possível diferença em relação às condições atuais pode ser atribuída à litologia. Assim, a Formação Adamantina teria níveis com maiores teores de ferro, os quais teriam sido alterados completamente nas cotas mais elevadas da paisagem, fornecendo ferro para os atuais ferricretes petroplínticos.

\section{CONCLUSÕES}

1. Os ferricretes foram formados no limite superior de oscilação do lençol freático, onde condições mais oxidantes prevaleceram. A atual configuração lateral dos horizontes na seqüência estudada comprova a designação de "ferricretes de Iençol freático" a esses materiais e evidencia a influência da rocha durante a segregação do ferro, através do controle do nível de oscilação do lençol freático.

2. Micromorfol ogicamente, as glébulas mostramse diferenciadas quanto à distribuição do esquel eto e do plasma. Algumas são predominantemente dominadas por esquel eto na fração areia muito fina, enquanto em outras predomina a fração média. Ainda existem glébulas em que o esqueleto é mal selecionado, variando em granulometria. Contudo, a maioria mostra uma fábrica interna dominada apenas por volumes de plasma. Fatores pedo-litobiológi cos estão envolvidos nessa diversidade entre glébulas num mesmo horizonte e que muitas vezes podem ser erroneamente interpretadas como de origem detrital.

3. As mai ores glébulas dos horizontes ferricretes, aqui identificadas como "ruiniformes", assemelhamse à uma fusão de glébulas menores. Evidências micromorfológicas confirmam essa impressão, bem como elucidam sua gênese: aportes de ferro nos estádios finais ou posteriores à formação das petroplintitas possivelmente foram responsáveis pela fusão de glébulas menores através de uma "ponte" ferruginosa intergl ebular.

4. Fatores climáticos ou associados à litologia podem ser responsáveis pela formação pretérita da petropl intita, os quais não se processam na paisagem atual, uma vez que há evidências de que os ferricretes estão se degradando. 
Figura 12. Pisolito de degradação do horizonte petroplíntico do perfil P2. Luz normal - 2,5x.

Figura 10. Fotomicrografia mostrando uma glébula plíntica do horizonte Cr (perfil P2). Diferentes domínios "cruzam"a glébula, originando verdadeiros "corredores" que ora são preenchidos com plasma apenas (paleocanais biolóticos - P), ora com plasma e quartzo triado nas frações areia muita fina e silte (paleopedotúbulos - C). Luz normal - 2,5x.
Figura 11. Fotomicrografia mostrando o interior das glébulas "ruiniformes" do horizonte F. (Perfil P2). Nota-se a "ponte" (P) entre as glébulas, promovendo sua fusão. Luz normal $-2,5 x$.

\section{AGRADE CIMENTOS}

Os autores agradecem à turma da Estação Experimental de Agronomia de Pindorama, especialmente aos colegas Dr. Antonio Lúcio Mello Martins e Dr. Luís Cláudio Paterno, pelo apoio logístico nos trabal hos de campo. À Prof. Dra. Selma Simões de Castro, pelas valiosas sugestões nas análises micromorfológicas.
Figura 13. Detalhes do córtex goethítico evidenciando o estádio de degradação das glébulas. Luz normal - 10x.

\section{REFERÊ NCIAS BIBLIOGRÁFICAS}

BATISTA, M.A. \& SANTOS, M.C. Morfologia e gênese de dois solos com plintita da Região Meio-N orte do Brasil. R. Bras. Ci. Solo, 9:287-296, 1995.

BEAUVAIS, A. \& COLIN, F. Formation and transformation processes of iron duricrust systems in tropical humid environment. Chem. Geol., 106:77-101, 1993.

BELLINFANTE, N.; PANEQUE, G. \& CLEMENTE, L. Estudio de las concreciones de un suelo de perfil complejo situado en la terraza del Guadalquivir de San Pablo (Sevilla). An. Edafol. Agrobiol., 29:477-483, 1970.

BIGARELLA, J . .; BECKER, R.D \& PASSOS, E. Estrutura o origem das paisagens tropicais e subtropicais: Intemperismo biológico, pedogênese, laterização, bauxitização e concentração de bens minerais. Florianópol is, Universidade Federal de Santa Catarina, 1996. 2v.

BOULET, R.; CHAUVEL, A. HUMBEL, F.X.\& LUCA, Y. Analyse structurale et cartographie en pédologie. Cah. ORSTOM Ser. Pédol., 19:309-351, 1982.

BOURMAN, R.P. Modes of ferricrete genesis: evidence from southeastern Australia. Z. Geomorphol., 37:77-101, 1993. 
BOURMAN, R.P.; MILNES, A.R. \& OADES, J .M. Investigations of ferricretes and related surficial ferruginous materials in parts of southern and eastern Australia. Zeitschrift Für Geomorphologie. Laterites, Someaspects of current reserch, 1987 p.1-24. (Supplementband, 64)

BREWER, R. Fabric and mineral analysis of soils. New York, Robert E. Krieger Publishing Company, 1976. 482p.

CASTRO, S.S. I mpregnação de amostras de sol os para confecção delâmina delgada. B. Inf. SBCS, 10:44, 1985.

CASTRO, S.S. Micromorfologia de solos - Pequeno guia prático para descrição de lâminas del gadas. São Paulo, 1989a. 87p. Mimeografado.

CASTRO, S.S. Sistema de transformação pedológica em Marília: B latossólicos e B texturais. São Paulo, 1989b, 274p. (Tese de Doutorado)

COELHO, M.R. Caracterização e gênese de ferricretes desenvolvidos do arenito Bauru, Formação Adamantina (Ka), no município de Pindorama (SP). Piracicaba, Escola Superior deAgricultura “Luiz deQueiroz", 1998. 233p. (Tese de Mestrado)

CURI, N.; LARACH,J .O.I.; KÄMPF, N.; MONIZ, A.C. \& FONTES, L.E.F. Vocabulário de ciência do solo. Campinas, Sociedade Brasileira de Ciência do Solo, 1993. 90p.

DANIELS, R.B.; PERKINS, H.F.; HAJ EK, B.F . \& GAMBLE, E.E. Morphology of discontinuous phase plinthite and criteria for its field identification in the Southeastern United States. Soil Sci. Soc. Am. J ., 42:944-949, 1978.

EMPRESA BRASILEIRA DE PESQUISA AGROPECUÁRIA EMBRAPA. Centro Nacional de Pesquisa de Solos, Rio de J aneiro. Sistema brasileiro de classificação de solos. Brasília, Produção de I nformação, 1999. 412p.

FAO/UNESCO/ISRIC. Soil map of the world. Wageningen, ISRIC, 1994. 140p.

IBANGA, I.J. The physical, chemical, and mineralogical properties of laterite samples formed in various environments. Raleigh, University of Raleigh, 1980. 120p. (Tese de Doutorado)

J IMENEZ-RUEDA, J.R. \& DEMATTÊ, J L.I. Solos originários de lamitos da formação Marília (Grupo Bauru) da região de Monte Alto, SP. R. Bras. Ci. Solo, 12:161-170, 1988.

LADEIRA, F.S.B. Estudo micromorfológico de um Latossol o Roxo no município de Guaíra - SP. São Paulo, Universidade de São Paulo, 1995. 93p. (Tese de Mestrado)

MARQUES J r., J . Distribuição e atributos dos solos em relaçãoà forma e evolução de uma vertente em Monte Alto, SP. Piracicaba, Escola Superior de Agricultura "Luiz de Queiroz", 1995. 228p. (Tese de Doutorado)

LEMOS, R.C. \& SANTOS, R.D. Manual de descrição e coleta de solo no campo. Terceira edição. Campinas, Sociedade Brasileira de Ciência do Solo- Centro Nacional de Pesquisa de Solos, 1996. 83p.
LEPSCH, I.F.; BUOL, S.W. \& DANIELS, R.B. Soil landscape relationships in the Occidental Plateau of São Paulo State, Brazil: Part I. Geomorphic surfaces and soil mapping units. Soil Sci. Soc. Am. J ., 41:104-109, 1977a.

LEPSCH, I.F.; BUOL, S.W. \& DANIELS, R.B. Soil landscape relationships in the Occidental Plateau of São PauloState, Brazil: Part II. Soil morphology, genesis and classification. Soil Sci. Soc. Am. J ., 41:109-115, 1977b.

LEPSCH, I.F. \& VALADARES, J .M.A.S. Levantamento pedológico detalhado da Estação Experimental de Pindorama, SP. Bragantia, 35:13-39, 1976.

McFARLANE, M.J . Lateriteand Landscape. New York, Academic Press, 1976. 151p.

McFARLANE, M.J . Laterites. In: GOUDIE, A. \& PYE, K., eds. Chemical sediments and geomorphology. London, Academic Press, 1983. p.7-58.

MILNES, A.R.; BOURMAN, R.P. \& NORTHCOTE, K.H. Field relationships of ferricretes and weathered zones in southern south Australia: A contribution to 'Laterite' studies in Australia. Aust. J . Soil Res., 23:441-465, 1985.

NAHON, D. Evolution of iron crusts in tropical landscapes. In: COLMAN, S.M. \& DETHIER, D.P., eds. Rates of Chemical Weathering of Rocks and Minerals. New York, Academic Press, 1986. p.169-191.

ROQUIN, C.; PAQUET, H.; FREYSSINET, P.; BOEGLIN, J.L. \& TARDY, Y. Lithodependence and homogeization of mineralogical and chemical composition of ferricretes. Chem. Geol., 84:124-137, 1990.

SIVARAJ ASINGHAM, S.; ALEXANDER, L.T.; CADY, J .G. \& CLINE, M.G. Laterite. Adv. Agron., 14:1-60, 1962.

SOARES, P.C.; LANDIM, P.M.B.; FÚLFARO, V.J . \& NETO SOBREIRO, A.F. Ensaio de caracterização estratigráfica do cretáceo no estado de São Paulo: Grupo Bauru. R. Bras. Geoci., 10:177-235, 1980.

TARDY, Y.; KOBILSEK, B. \& PAQUET, H. Mineralogical composition and geographical distribuition of African and Brazilian periatlantic laterites. Theinfluence of continental drift and tropical paleoclimates during the past 150 million years and implications for India and Australia. J . Afr. Earth Sci., 12:283-295, 1991.

TARDY, Y. Pétrologie des latérites et des sols tropicaux. Paris, Masson, 1993. 459p.

TARDY, Y. \& NAHON, D. Geochemistry of laterites, stability of $\mathrm{Al}-\mathrm{Goethite}, \mathrm{Al}-\mathrm{H}$ ematite, and $\mathrm{Fe}^{+3}$ - kaolinite in bauxites and ferricretes: An approach tothe mechanism of concretion formation. Am. J . Sci., 285:865-903, 1985.

TARDY, Y. \& ROQUIN, C. Geochemistry and evolution of lateritic Iandscapes. In: MARTINI, I.P. \& CHESWORTH, W. Weathering Soils \& Paleosols. Guelf, Elsevier, 1992. p.407433.

WRIGHT, V.P.; SLOAN, R.J .; GARCÉS, B.V. \& GARVIE, L.A.J . Groundwater ferricretes from the Silurian of I reland and Permian of the Spanish Pyrenees. Sedim. Geol., 77:37-49, 1992. 
M.R. COELHO et al.

R. Bras. Ci. Solo, 25:371-385, 2001 